\title{
AFGANISTÁN EN LOS TIEMPOS DE LOS TALIBANES. UNA MIRADA RETROSPECTIVA
}

\author{
Emilio Asti \\ Università Cattolica de Milano \\ (Profesor italiano, experto en Culturas Orientales)
}

https://doi.org/10.33676/EMUI_nomads.55.12

Resumen.- En este artículo se ofrece un análisis del régimen talibán, basada también en la experiencia personal del autor, acompañada de estudios y múltiples conversaciones, tratando de explicar el origen y el desarrollo de aquel sistema de gobierno en el marco del contexto afgano de entonces, ilustrando también sus principales rasgos, fundamentados sobre una interpretación muy estricta de la ley coránica.

Palabras clave: Afganistán, Islam, Alá, Talibán, Mulá Omar, Sharia, Yihad

\section{Afghanistan in the times of the talibanes. A retrospective look}

Abstract.- This article presents an analysis of the Taliban regime, based also on the author's own experience, in addition to research studies and various conversations, trying to explain the origin and the development of that government system within the Afghan context at that time, illustrating also its main features founded on a very strict interpretation of the Coranic law.

Keywords: Afghanistan, Islam, Allah, Taliban, Mullah Omar, Sharia, Jihad

Nombrado oficialmente "Emirato Islámico de Afganistán", bajo el régimen talibán Afganistán era un mundo extraño, encerrado en un código espiritual muy estricto, en el cual fervor religioso y recelo hacia todo lo foráneo se mezclaban. En aquel entonces, quien visitaba Afganistán veía un país fuera de lo común, aún en condiciones miserables, envuelto en una dimensión autárquica, tibre de turistas y de hombres de negocio, que daba la impresión de haber salido de otro tiempo. No se oían gritos publicitarios y tampoco había agobio de petición al visitante extranjero; un poco antes de la noche, el silencio, interrumpido sólo por la llamada a la oración era total, todo se paraba y la gente estaba ya en sus casas.

Convertido en un bastión del fundamentalismo, en el cual era en vigor la aplicación integral de la ley coránica, a cuyas obligaciones nadie podía escapar, el Afganistán de aquella época ofrecía un aspecto muy uniforme; mirara donde mirara, por extraño que pudiera aparecer, en 
las calles uno veía sólo hombres con barba y muy pocas mujeres, todas tapadas con el burka, que en público iban acompañadas con un familiar varón y guardaban silencio, muestra del austero estilo de vida que se desarrollaba allí. Única apariencia de modernidad eran los todoterrenos que usaban los milicianos talibanes, los cuales, con turbantes y rostros barbudos, presentaban todo el mismo aspecto, que todavía está en la memoria de muchos afganos.

\section{El movimiento talibán: origen e ideología}

Lo que sabemos de los Talibanes, una palabra que no tiene buena prensa y que a fecha de hoy sigue siendo tema de discusiones, se debe, principalmente, a lo que los medios de comunicación han relatado, pero hasta ahora muchos aspectos, todavía no esclarecidos, son objeto de conjeturas; abundan generalizaciones al respeto y múchos interrogantes sobrevuelan este asunto, aún rodeado de misterio. En Occidente se sabía poco sobre ellos, puesto que generalmente los periodistas, al asumir la figura de un sistema proclive al fanatismo, han tratado los Talibanes solamente como musulmanes muy radicales; varios datos han sido descuidados y muchos artículos han convertido a los afganos en unos sospechosos de terrorismo, sin dejar espacio para un análisis más objetiva. La definición del movimiento talibán, el cual ha tenido su origen en un escenario muy conflictivo y complejo, aún no ha sido suficientemente aclaratoria, y se hace preciso considerar diferentes factores y superar esquemas de investigación reduccionistas. Limitar la perspectiva del análisis del régimen talibán a la dimensión religiosa, puede proporcionar una imagen incompleta de eso, que se inscribía en el plano de una situación compleja, que tenía que ver con unos diseños extranjeros. La historia de los Talibanes debe ser analizada dentro de la trágica condición en que estaba sumido Afganistán, de la que no parecía encontrar salida, teniendo también en cuenta el papel de Pakistán en este asunto.

Después de la retirada de las tropas soviéticas, las diferentes facciones, que habían combatido para liberar el país, empezaron a luchar ferozmente entre sí, con-bombardeos y lanzamiento de mísiles; como consecuencia, Afganistán acabó dividido en varias zonas bajo el dominio de señores de la guerra, que se peleaban mutuamente, y cuyos pasos eran marcados por el saqueo y los asesinatos. La inseguridad había llevado muchos a buscar la protección de aquellos, en cambio de la sumisión a sus órdenes. En la dramática historia de aquel tiempo, el crimen, protagonizado por bandas incontroladas que se apropiaban de casas y granjas y también raptaban mujeres, era una forma natural de ejercer el poder; prostitución y uso de las drogas eran difundidos a gran escala y las mafias del transporte exigían peajes para 
circular. Así estaban las cosas cuando los Talibanes hicieron su aparición en el escenario afgano en 1994 (Requena, 109-110).

Casi todos de etnia pastún, el grupo étnico mayoritario de Afganistán, los Talibanes, así llamados, al proclamarse estudiantes islámicos, de hecho, la palabra Talib, de origen árabe, que significa estudiante, eran jóvenes de humilde origen, la mayoría de los cuales crecidos en los campos de refugiados de Pakistán y educados en las madrazas de aquel país. Ellos, muchos de los cuales hacían gala de haber participado en la lucha contra los invasores soviéticos, llevaban una vida austera y ajena a las diversiones modernas, casi como miembros de una cofradía varonil, que no parecían interesados al poder, sino en la restauración del orden y la moralidad, sin embargo, poco propicios a definir claramente sus planes. Numerosos afganos se preguntaban, con cierta aprensión, quienes eran de verdad estos jóvenes combatientes poco antes desconocidos.

Las raíces de su emergencia se encuentran también en la entramada situación regional. No hay que olvidar que el movimiento talibán, que podía contar con el visto bueno de unos países, era apoyado sobre todo por Pakistán, que les había proporcionado ayuda militar y entrenamiento y cuyo objetivo era poder contar con un régimen amistoso y estable a la vez, que, en caso de conflicto con la India, pudiera asegurar su frontera occidental. Para Pakistán, que ya durante la invasión soviética, alineándose con los EEUU, había apoyado a los Muyahidines afganos, proporcionándoles suministros y refugios, era importante asegurarse un grado de influencia en los asuntos afganos.

¿Quién iba a imaginar que estos jóvenes desconocidos, irían a convertirse en los gobernantes de Afganistán? En medio de un ambiente de conflicto y degeneración moral, la victoria de estos sorprendió a muchos., que la vieron con mucha ilusión. Al comienzo incluso EEUU habían considerado el régimen talibán, como algo que podría poner fin a la larga situación de anarquía y conflicto.

¿Quién iba a imaginar que estos jóvenes desconocidos, irían a convertirse en los gobernantes de Afganistán? En medío de un ambiente de caos y degeneración moral, la victoria de tos Talibanes sorprendió a muchos.

Descritos como un grupo pequeño, pero compacto y militante, los Talibanes, que predicaban una interpretación muy estricta de la ley coránica, y habían hecho de la lucha contra la violencia y la corrupción el principal motivo de su legitimidad, se convirtieron en los dirigentes del país.

Después de varios años de violencia y sufrimiento, transcurridos durante la ocupación soviética y la guerra civil, que se habían cobrado muchas víctimas, los Talibanes se hacían intérpretes del anhelo a la paz, y con sus operaciones mostraban de estar cerca de los marginados, 
oponiéndose a los criminales. Sus primeras medidas fueron el desarme de las milicias que perjudicaban a la población y la aplicación de castigos severos a los que infringían las normas coránicas. Resueltos a extirpar todas las tendencias consideradas pecaminosas, los miembros del movimiento talibán, que no emitían comunicados de prensa ni concedían entrevistas, se caracterizaban por la adhesión a una disciplina estricta, sin escatimar ningún sacrificio personal. Hombres de fuerte determinación y de convicciones profundas, los Talibanes, aunque en mayoría incultos, sin embargo, se ganaron el respeto de muchos, a los ojos de los cuales parecían elegidos por Alá para acabar con un pasado de violencia y corrupción. En su opinión, la victoria de los Talibanes venía marcada por el sello de la ayuda divina e inauguraría una época de paz.

Toda influencia extranjera, considerada el origen de los males que aquejaban a Afganistán, era condenada con rigor por los Talibanes, los cuales afirmaban de haberse consagrado a continuar la tarea empezada por los Muyahidines, y que con su llegada al poder se había puesto en marcha la creación de una nueva sociedad verdaderamente islámica. Cuando entraron en Kabul en Septiembre de 1996, su primera acción fue ahorcar al ex presidente Najibullah, el último gobernante comunista de Afganistán, que había gozado del apoyo de la URSS. Después de duras batallas, en 1998 lograron conquistar el Norte del país, sufriendo muchas pérdidas (Segura, 197) y solamente unas zonas quedaban fuera del control del gobierno talibán. La principal era el Valle del Panjsir, una estrecha franja en la parte nororiental de Afganistán, que estaba bajo la autoridad de una formación militar llamada "Alianza del Norte", liderada por el comandante tayiko Ahmed Shah Masud, el cual, apoyado por algunos Estados, luchaba contra los Talibanes y será matado dos días antes del 11 de Septiembre. Varias veces los Talibanes intentaron llegar a un pacto con él, pero nunca se realizó un acuerdo entre las dos partes, debido a las profundas diferencias que les separaban. En unas áreas seguían ocurriendo combates entre las fuerzas talibanes, que querían acabar con los últimos focos de resistencia, y las de la Alianza del Norte.

Hablar de los Talibanes significa considerar sobre todo el papel de su líder, el mulá Mohammed Omar, el cual dejó una huella imborrable en la historia afgana. Pocos líderes musulmanes cautivaron la atención más que él, cuyo nombre aún hoy en día en Occidente evoca temores; todos lo conocemos por haberse asociado con Bin Laden, pero en torno a su vida se había levantado un muro de silencio. Uno de los más enigmáticos dirigentes de nuestra época, el mulá Omar, cuya fecha y lugar exacto de su nacimiento no se saben con certeza, jamás fue entrevistado por periodistas occidentales; se conocía su total aversión a ser fotografiado y su imagen no se veía en ningún sitio. Procedente de una humilde familia de campesinos de la zona de Kandahar, se sabía que había luchado con valor contra la ocupación soviética y que 
perdió el ojo derecho durante los combates. Descrito como un hombre de carácter reservado, de constitución robusta y alta estatura, se reveló no cómo un simple clérigo, sino también cómo un jefe político, en cuyas palabras se percibía un tono profético, presentándose también como un restaurador dentro del Islam, si bien carecía de conocimientos académicos. El tono de sus discursos, que inflamaban la imaginación de muchos, iba en la línea de una concepción de la historia vista como un continuo enfrentamiento entre el campo de los creyentes y aquello de los infieles, afirmando que la misión de Afganistán estaba vinculada con el objetivo de la destrucción del mal y la victoria del Islam en el mundo, presentadas como un futuro inevitable. Omar demostró una obstinada determinación a realizar su propia visión, independientemente de las consecuencias, y, con una aparente carga de ingenuidad, creía posible lograr rápidamente la creación de una nueva sociedad en total armonía con la ley coránica.

Se podía calificar al mulá Omar de visionario con una imaginación atrevida y ardiente, el cual se había forjado la reputación de combatiente ejemplar en todo y exigente consigo mismo, que se veía como un salvador para su pueblo; su elevación al poder desde inicios muy humildes contribuyó a hacerlo excesivamente confiado en la importancia de su misión. Sus seguidores reforzaban su imagen de líder espiritual y se narraba que el mulá Omar, del cual destacaba su inclinación a las experiencias místicas, había recibido una revelación, la cual lo había empujado a comprometerse a la misión de salvar Afganistán; eso lo hizo sentirse un individuo especial, escogido por Alá para cumplir con una importante misión espiritual Los analistas han puesto poca importancia en este aspecto, que, en cambio, para los Afganos ha desempeñado un papel importante. Los a su alrededor contaban que llevaba una vida ascética, alejada de las comodidades propias de un jefe de Estado, desprendiendo el dinero, y transmitía órdenes y nombramientos escritos en papelillos, y además no aceptaba visitas de extranjeros no musulmanes, lo que hacía sino acrecentar su condición de leyenda. Era patente un culto carismático a él, sin señas exteriores, sino guardado profundamente en los corazones.

En Abril de 1996, el mulá Omar hizo sacar el Manto que se decía haber pertenecido al profeta Muhammad, guardado en una mezquita de Kandahar y que se había exhibido en muy pocas ocasiones, cubriéndose con ello, por legitimar su papel de elegido de Alá y ser aclamado como "Emir de los creyentes", casi como si con este gesto quisiera asumir hasta el liderazgo de todos los creyentes musulmanes (Rashid, 96-97).

Los Talibanes hicieron de Kandahar, donde el Mulá Omar había construido su residencia, el centro de su actividad y allí se encontraba la Shura, el consejo directivo talibán, cuyas decisiones se basaban sobre las opiniones de él (Batalla, 171). El verdadero centro del poder talibán no era Kabul, donde el Mulá Omar había ido sólo unas pocas veces, 
sino Kandahar, antigua ciudad situada en el Sur del país, en la intersección de importantes rutas, la cual tiene una relevancia especial en la historia de Afganistán. Lugar emblemático del nacionalismo pastún, Kandahar fue la primera ciudad ocupada por los Talibanes y el Tribunal Supremo Islámico de esta ciudad se convirtió en el más importante del país. Desde allí el mulá Omar, más una figura emblemática que un jefe de Estado, que conocía poco el resto del país, dirigía los asuntos del gobierno, rodeado de una corte de mulás que hacían las funciones de secretarios y portavoces. Precisamente, fue en esta ciudad que él se atrincherará en la última resistencia durante el ataque de EEUU contra Afganistán al final de 2001.

\section{Dimensión espiritual y dinámicas políticas del gobierno talibán}

Único en su organización y objetivos, el movimiento talibán, cuya estructura militar estaba envuelta en secretismo, no tiene precedentes en Afganistán. El establecimiento del régimen talibán, que constituyó el primer ensayo del radicalismo islámico que se asienta como Estado, cuya singular naturaleza religiosa y jurídica reviste una significación particular, representa un escenario de permanente debate para los estudiosos.

La comparación del régimen talibán, que se consideraba la versión más rigurosa del Islam, basada en una forma de radicalismo místico, con otros sistemas islámicos puede resultar equivocada. Quienquiera intente entender la compleja realidad del movimiento talibán, debe tener en cuenta su carácter marcado por una dimensión mística, en la cual la historia real es velada, pero todo criterio interpretativo choca con un sistema de valores muy diferentes de la lógica occidental.

Aunque el radicalismo religioso haya sido ajeno a la tradición espiritual afgana, hay que reconocer que el régimen talibán no representa algo totalmente nuevo en la cultura afgana, puesto que los afganos tenían la predisposición a creer en el papel de líderes espirituales, capaces de cambiar el rumbo de la historia.

En su visión, que los Talibanes nunca trataron de presentar en una exposición orgánica, unos principios se remontaban al Pastunwali, el antiguo código de conducta pastún, cuyo criterio básico es un profundo sentido del honor, al cual se añadían una dosis de mesianismo y una fuerte componente de nacionalismo religioso, acentuado por encontrarse el país largo tiempo en situaciones de opresión y rodeado de hostilidad. También la influencia del Wahabismo y del Deobandismo, además de pensadores como Maududi y al-Banna, interpretados de manera peculiar, ha sido importante (de la Torre, 69). Su política, enfocada en emular el Islam primitivo y que asumía la Sharia, interpretada desde una perspectiva particular, como fundamento del 
Estado, se acompañaba con una interpretación del Corán hecha bajo las influencias de una atávica mentalidad tribal. La condena del materialismo occidental se convierte en una exigencia defensiva, como una reacción a la política de agresión y desprecio por parte de varios países, además como una respuesta desafiante a cualquiera influencia extranjera.

Sin adentrarse en análisis profundas, se puede afirmar que los Talibanes, que vivieron la ilusión de haber inaugurado una nueva etapa histórica, no se consideraban a sí mismos en términos de políticos, sino de guías espirituales, continuadores de la misión de los primeros califas, para los cuales el ejercicio del poder representaba un deber religioso, además de un servicio a Alá. Para ellos, que tenían la meta de transformar a Afganistán en el Estado islámico más puro del mundo, todos los asuntos eran, en última instancia, cuestiones espirituales, la solución de las cuales se encuentra en la aplicación de la Sharia, cuyas normas, únicas garantes de la creación de un mundo de paz, conservan su valor por encima de los siglos.

Su proyecto, caracterizado por el ardiente deseo de forjar un camino de regeneración espiritual adecuado a la realidad afgana y construido sobre la oposición con el resto del mundo, les granjeó muchos enemigos.

En su ideología, hecha de orgullo y utopías, varios aspectos de la cual eran nebulosos, la diferencia entre lo ideal y lo real quedaba oscurecida. Con un liderazgo impredecible, marcado por el dogmatismo y el misterio, parecía un régimen desestructurado, cuyos funcionarios carecían de toda idea de Estado y debido a una decisión del Mulá Omar, sus cargos podían intercambiarse en cualquier momento. Muchos miembros de las Shuras de Kandahar y de Kabul, en algún momento, actuaban como jefes militares y los gobernadores eran variados con frecuencia.

Aunque la dirección política fuera colectiva y consultiva, el poder estaba concentrado en manos de Omar, como declaró un estrecho colaborador de él en una entrevista con una revista árabe:"...No habrá un jefe de Estado, sino un Amir-ul Monimeen (Emir de los creyentes). El mulá Omar será la primera autoridad y el gobierno no podrá poner en práctica ninguna decisión con la que él no esté de acuerdo..."

Puesto que la concepción de los Talibanes era la de una sociedad teocrática, eso exige que el gobierno, cuyos objetivos tienen que ir mucho más allá de la dimensión política, esté en mano de una vanguardia de verdaderos creyentes, que ejercen la autoridad en nombre de Alá, considerado el supremo soberano del Estado y de todos los asuntos humanos, y tengan por cometido la imposición de la verdad y la supresión de lo que es falso... En este contexto, el Islam, cuyo aspecto tolerante fue suprimido, tomó la forma de un dogmatismo autoritario, en el cual todo debate era proscrito y solamente cabían 
relaciones de dominio y sumisión. En opinión de los Talibanes, la ausencia de un gobierno islámico implica el desorden y el conflicto y sólo en un Estado como éste los creyentes podrían encontrar la satisfacción de sus necesidades espirituales. La democracia, puesto que proclama la soberanía del hombre y no la de Alá, era considerada incompatible con el Islam; la afirmación de la autonomía del ser humano, cuyo fin último son el servicio y la adoración a Alá, supone un desafío a Él. Un portavoz talibán explicó: "La Sharia no permite política o partidos políticos. Esta es la razón por qué no damos salario a los oficiales y soldados, sólo comida, ropa, zapatos y armas. Queremos vivir una existencia como el Profeta vivió hace 1400 años, y la Yihad es nuestro derecho. Queremos recrear la época del Profeta, y sólo estamos llevando a cabo lo que el pueblo afgano ha querido durante los últimos años".

Según ellos, la vida en Afganistán debía imitar la organización de la comunidad del Profeta Muhammad y sus primeros seguidores, cuando se había desarrollado una sociedad acorde con la voluntad de Alá, completamente exente de idolatría, en la cual cada uno cumplía con los deberes religiosos y no había lugar para las transgresiones. Por su vigor espiritual aquella comunidad de creyentes, que puede considerarse el modelo para todos los musulmanes, fue capaz de difundir el Islam por muchas partes y resistir la penetración de prácticas paganas a la vez. Las costumbres de aquel tiempo, considerado un hecho decisivo en la historia y colocado en un plan ideal, sin tener en cuenta los cambios históricos, para los Talibanes resultaban aplicables a la situación presente y les servían como agente legitimador.

La premisa indispensable era que todo lo que no era conforme al Islam tenía que desaparecer y era total el rechazo a la modernización, vista como una amenaza a las tradiciones islámicas, y bajo la cual estuviera camuflado el proyecto de reducir Afganistán a la condición de lacayo de intereses ajenos. En acuerdo con esta perspectiva, había sido adoptado oficialmente el calendario islámico y todos los funcionarios gubernamentales, incluido los ministros, llevaban una vida muy sobria, pero sabían manejar bien la tecnología moderna, difundiendo comunicados a través de un sitio web.

Una vez en el poder, los Talibanes al pretender realizar una sociedad libre de vicios, quisieron mantener vivo el espíritu de la Yihad a través de la imposición de un estilo de vida finalizado a que los afganos nunca pudieran perder su celo religioso. Puesto que los Talibanes pretendían forjar nuevos modelos de comportamiento y extirpar las conductas consideradas erróneas, cada aspecto de la vida, hasta los más pequeños detalles, debía conformarse a la ley coránica; toda innovación, a juicio de los Talibanes, contraria a la Sharia, era rechazada firmemente. Convencidos de que el relajamiento religioso es el origen de crisis sociales, los Talibanes pretendían eliminar cuanto de contrario al Islam hubiera en la vida cotidiana y recomendaban 
comportamientos preventivos finalizados a desalentar cualquier tipo de conducta que sea contraria a las normas de la Sharia, como una continua campaña de reeducación espiritual, finalizada a arrancar del alma todas las malas inclinaciones. En su opinión, el ser humano, en tanto que no elimine de sí las inclinaciones pecaminosas y todo lo que lo ate demasiado a la dimensión material, no puede alcanzar la salvación. A tal fin las mentes de las personas deberían estar siempre orientadas hacia Alá, pronunciando con frecuencia palabras de alabanza y de agradecimiento a Él, cuya misericordia hay que buscar en todo momento, puesto que el hombre está llamado por Alá a vivir en la obediencia a Sus leyes; el ser humano es débil y nada puede por sí solo, cuando uno quiera organizar su vida sobre la convicción de su libertad incondicionada, se engaña.

Cada persona debía mostrar obediencia de manera incondicional a Alá y a las autoridades, observando estrictamente sus mandatos, formalizados en varios edictos. Todo esto hacía parecer Afganistán como un gran monasterio, en el cual cada uno debía controlar de continuo su conducta, y además actuar de vigilante moral de los otros. Todos tenían que seguir estrictamente las instrucciones dictadas para mantener el orden, y toda clase de indisciplina era duramente aplastada. La radio oficial "La vOz de la Sharia" invitaba repetidamente a la observancia de las normas con la amenaza de castigos en la tierra y del infierno después de la muerte a quienes no cumpliesen con ellas. Un aparato propagandístico, con camiones equipados con altavoces, folletos y carteles, transmitía las consignas de los Talibanes, y en las mezquitas se predicaba la necesidad de convertirse en creyentes libres de dudas y anhelos innecesarios, que no pueden contentarse con una vida espiritual a medias tintas. También se aconsejaba la renuncia a lo superfluo a favor de una entrega completa a Alá, ya que el deseo excesivo hacia la posesión de bienes materiales acaba por obstaculizar el camino espiritual. Solo existe un dueño absoluto de los bienes del mundo: Alá, el cual conoce lo que realmente el ser humano necesita; en este sentido Afganistán se podía calificar como una sociedad de no consumo, en la que había de contentarse con muy poco.

Ya todos los niños tenían que memorizar los versículos del Corán, en la convicción de que este texto sagrado revele la más total verdad sobre el ser humano y su destino, y a través de la aplicación de sus normas, todos los problemas se pueden resolver. Estimando que muchas ideas fuesen peligrosas y cuya manifestación debía ser restringida, cualquier estudio que no fuera él del Corán y de la Sunna, considerados la más importante fuente de sabiduría, además de herramienta fundamental para desarrollar la personalidad y vencer todo obstáculo, se estimaba inútil. Los educadores se empeñaban en la tarea de transmitir a los chicos el anhelo por la Yihad, como esfuerzo para abrazar el sacrificio y la renuncia y también en sentido de la lucha por la defensa de los valores islámicos. A fin de formar jóvenes que Alá pueda utilizar como 
Sus instrumentos, para quienes la religión es algo muy importante, los niños eran educados con el ejemplo de los Muyahidines y se les recomendaba prepararse de manera consciente y vigorosa para estar en cada momento en condiciones de defender al país, sin temer nada. Se alegaba que los Talibanes reclutasen jóvenes para servir como soldados, obligándoles a combatir contra su voluntad.

En la vida diaria siempre había que anteponer las obligaciones espirituales a todo otro compromiso y a la hora de la oración cualquier actividad tenía que interrumpirse para dedicarse a rezar, pero participar a la oración no eximía del deber de estudiar el Corán. Todos eran obligados a acudir a la mezquita, la falta de participación a las oraciones, que habían dejado de ser un asunto privado quedando reducidas al cumplimiento de una obligación gubernamental, representaba un pecado punible, cuando no existieran motivos razonables para abstenerse. Un decreto ordenaba de evitar que no se rece y que la oración, estimada importante para purificar el alma y fomentar buenos sentimientos, debiera tener lugar a su debido tiempo en todos los distritos y el transporte estaría estrictamente vedado.

Para los que se convirtieran a otra religión y para cualquier persona que provocase la conversión de un afgano, estaba en vigor la pena de muerte. En ningún caso estaba tolerado hacer propaganda de otras religiones, ni tampoco se permitían sus manifestaciones externas; unos empleados de una ONG occidental fueron detenidos y luego expulsados del país por ser acusados de propagar el Cristianismo. No estaba permitida otra forma de practicar el Islam que no fuese la que imponían los Talibanes, cuya doctrina no dejaba margen a la interpretación, así que sobre los musulmanes Chiíes se cernía la amenaza de persecución. Dado que los Chiíes eran vistos como practicantes de la idolatría y sospechosos de inclinación hacia Irán, los Hazaras, grupo étnico minoritario y Chiíes, acusados con frecuencia de conductas delictivas, sufrieron muchas discriminaciones y ataques. Aquellos nunca perdonaron a los Talibanes la muerte de su jefe, Abdul Ali Mazari, ocurrida en 1995, cuando estaba bajo custodia de éstos.

Aunque no se encontraran a gusto con un sistema demasiado restrictivo, los Afganos no tenían otro remedio que aceptar las consignas de los Talibanes, que, aunque muchas de las cuales chocaran con las costumbres tradicionales, no podían ser puestas en tela de juicio; una toma de posición pública en este sentido resultaba arriesgada y la gente mantenía sus opiniones a buen recaudo de la policía religiosa.

Puesto que el gobierno había dado orden de perseguir con severidad cualquier acto de inmoralidad, en las ciudades no había espacios libres de la vigilancia de la policía religiosa, que actuaba bajo la orden del Ministerio de la Represión del Vicio y la Promoción de la Virtud, uno de los más importantes órganos del gobierno talibán (Etienne, 88). Como 
bien indica el nombre, sus milicianos, dedicados a reprimir toda ofensa a la moralidad, recorrían las calles a la caza de los que se atrevían a desobedecer a las normas, castigando todos los comportamientos que, a su juicio, resultasen inconvenientes. Como podían atestiguar muchos por propia experiencia, los milicianos talibanes, varias veces ejercían su poder de forma arbitraria e imponían las normas a golpes de látigo, sin mostrar misericordia hacia nadie.

Dado que, a juicio de los Talibanes, el orden moral es la base de la armonía social y un pecado de inmoralidad causa daño a la sociedad entera, además de provocar la cólera divina, ta homosexualidad y el adulterio, contra los cuales habían sido promulgados edictos muy severos, eran sancionados con gran dureza. En el intento de desarraigar completamente el consumo y el tráfico de drogas, que representaba una importante fuente de ingresos, toda clase de substancia estupefaciente no estaba permitida, bajo duras penas; incluido el cultivo de la adormidera y la siembra de cualquier planta de aquel tipo se habían prohibido, pero el número de los drogadictos era todavía alto.

Desde el comienzo, el uso de los castigos corporales fue un aspecto relevante del régimen talibán, para el cual la aplicación de una pena era como un acto educativo, con el intento de hacer reflexionar cada uno sobre las graves consecuencias que producen los delitos. Los que infringían la ley, vistos como enemigos del Islam y del Estado, eran castigados duramente en público y se practicaban mutilaciones de brazos y piernas para los malhechores, medidas que suscitaron la reprobación de la comunidad internacional. En nombre de la necesidad de eliminar todos los elementos considerados malos, que además podrían contagiar los demás, la pena capital era aplicada por una amplia variedad de delitos; muchas personas habían sido detenidas sin cargo ni juicio y varias fueron ajusticiadas sin juicio previo. No cabía en absoluto la posibilidad de recuperación de los reos, los cuales quedaban expuestos a la vergüenza pública.

Bajo la idea de que la televisión, la música y el baile sean antiislámicos y lleven a la corrupción moral, fueron vetados, alegando que la privación de la televisión y de la música es una condición que permite al espíritu de fortalecerse y dejar espacio a las inspiraciones de Alá a la vez. Afganistán era el único país del mundo donde no estaba permitida la música, incluido durante las bodas y las fiestas, y se convirtió en el solo Estado sin himno nacional; muchos músicos habían sido encarcelados y sus instrumentos destruidos. Lo que más afligió los Afganos fue la prohibición de la celebración del Nawroz, el primer día del año nuevo, considerado incompatible con el Islam. Escuchar música, incluido tener cintas, se había declarado ilegal, sobre la convicción de que las películas tratasen asuntos frívolos, y que las canciones llevasen a olvidar los deberes religiosos. Sólo por haber tenido cintas de música, traídas de contrabando desde Pakistán, desafiando los edictos talibanes, se 
penalizó severamente a varias personas. No hay que sorprenderse de que en aquel clima de intolerancia cintas de video, fotos y muchos libros fueron quemados y los cines habían sido derribados 0 transformados en salas de oración, hasta los baños públicos de Kabul fueron cerrados. A cada momento la policía religiosa podía registrar las tiendas, muchas de las cuales habían sido clausuradas. El gobierno decretaba cuales libros habían de publicarse y cuales debían usarse en la enseñanza. Debido a que el gobierno talibán estaba en contra de todo patrimonio cultural que no formase parte del acervo islámico, muchas estatuas y objetos antiguos, incluido obras de arte en el Museo de Kabul, considerados incompatibles con el Islam, fueron destruidos y de tal manera se perdieron varios vestigios culturales. Por ser representaciones de seres vivos, todas las imágenes tenían que ser eliminadás, y en cualquier lugar no se podía exponer fotos ni retratos; incluso muñecas y peluches fueron prohibidos. Eso se debía a que las imágenes eran asociadas con la idolatría, vista por los Talibanes como el origen de todos los males, puesto que no hay nadie merecedor de adoración sino Alá, y lo que se adore fuera de Él es falso; la sumisión a Alá no es completa sin la renuncia a todos los ídolos, los cuales son obras humanas y por lo tanto no pueden salvar. Desde el inicio de su gobierno, defender la población de las creencias erróneas se había convertido en una prioridad, que había ido adquiriendo una importancia obsesiva, y con el fin de liberar el alma del sometimiento a falsas deidades e impedir que el engaño se impusiera a la verdad, los Talibanes se opusieron con fuerza a las prácticas vinculadas con la magia y las supersticiones, sobre cuyos partidarios caían decretos de dura condena. La lista de prohibiciones se extendía a no poder fumar, y hasta unos pasatiempos como jugar a las cartas eran motivo de sanción. Estaba también vetado jugar con las cometas, considerado peligroso y como algo que podría distraer los niños del aprendizaje. Incluido unos deportes fueron suprimidos, además de todos los juegos de azar y las apuestas, y sus aficionados conocieron malos días; las autoridades talibanes veían en estas distracciones algo que puede corromper las personas y alejarlas del camino espiritual, pero la condena de estas prácticas no supuso su fin.

Los Talibanes también quisieron introducir la moralidad en el mundo de los negocios, condenando cualquier trato comercial que provocara injusticia $O$ inmoralidad. Comerciantes deshonestos, individuos explotadores y mentirosos debían ser castigados, y muchos fueron despedidos de su trabajo.

Incluido en el ámbito de la indumentaria, las personas debían conformarse a las prescripciones oficiales. Todas las maneras de vestir que podían estimular la vanidad eran tachadas de anteislámicas. Obligados a usar la vestimenta tradicional y llevar barba, cuyo tamaño, controlado por la policía religiosa, tenía que medir la longitud de un puño, los varones, de los cuales nunca se cuestionaba la superioridad, 
debían mantenerse leales con su naturaleza varonil y evitar cuanto pudiera deshonrar su carácter; se condenaban los hombres que actuaban con modales femeninos y las mujeres que se comportaban con modelos masculinos. Los hombres que llevaban pelo largo, calificado como una mala costumbre, propia de Occidente, eran detenidos y se les cortaba el pelo. Estas medidas se aplicaban con especial virulencia en las ciudades, mientras en las zonas rurales el control no era tan riguroso.

Debido a la opinión de los Talibanes que consideraban la mujer "un ser débil y vulnerable a tas tentaciones", las mujeres estaban sometidas a una permanente tutela varonil, sin poder decidir sobre sí mismas y privadas de la posibilidad de disponer de sus bienes. Acerca de eso, el Ministro de Educación había dicho: "Tener una mujer es como tener una flor, se le agrega agua y se la mantiene en casa para que uno la vea y la huela. No debe estar fuera de la casa para que otros la huelan". En ningún otro lugar del mundo, incluido Arabia Saudí, la separación entre los sexos era tan profunda; cualquier tipo de cortejo y de amistad entre chicos y chicas se consideraba como algo pecaminoso que atentaba contra la tradición, dado que las bodas tenían que ser arregladas por las familias, sin oportunidad de libre elección de la pareja. Todo lo que las mujeres aprendían era lo relacionado con las tareas domésticas y ellas no debían participar en los asuntos públicos. Para evitar que los varones cayeran en la tentación por causa del portamiento femenino, en cada sitio estaba vigente una separación entre el espacio reservado a las mujeres y los sectores reservados a los hombres; incluido los autobuses, cuyos choferes no debían ser vistos por las pasajeras, estaban divididos en dos partes, en una estaban los hombres y en la otra las mujeres. En los hospitales públicos los médicos varones no podían atender a una paciente (Rashid, 412-415); a los sastres no era permitido confeccionar ropa femenina y tomar medidas a las señoras. En este contexto de segregación total, las mujeres no podían tener el más mínimo contacto con un hombre que no fuera su marido o un miembro de la familia y las que salían de su casa, podían hacerlo solo bajo la compañía de un varón de la familia, poniéndose el burka, sin llevar tacones altos, tampoco debían mostrar el tobillo ni maquillarse y pintarse las uñas; también se les había prohibido lavar ropa en los ríos y en otros lugares públicos. Los maridos eran responsables de la conducta de sus esposas y de sus hijas, y en caso de una mujer que se portara mal, el marido era castigado. Lamentablemente la prohibición del trabajo femenino fuera del hogar ha tenido consecuencias negativas, puesto que debido a la guerra, muchas mujeres, cuyos maridos murieron o se quedaron inválidos, eran el único sostén de la familia. Los colegios femeninos habían sido cerrados, pero en forma clandestina se impartían clases de alfabetización para mujeres, algunas de las cuales organizaban escuelas en sus casas (Bernabé, 32). Al hablar con un responsable gubernamental sobre la condición de las mujeres, 
éste afirmaba que, a diferencia de Occidente, donde, en nombre de una supuesta libertad, la mujer, cuya desnudez expuesta en público es el símbolo más claro de la degradación moral, ha quedado reducida a mero objeto sexual a fines publicitarios, el intento del gobierno afgano era garantizarle una vida virtuosa, al amparo de la familia y en armonía con el papel asignado a ella en el Islam, dado que la conducta indecente de las mujeres provoca la perdición de sus familias. Estas eran, sustancialmente, sus afirmaciones, explicadas con firmeza y serenidad a la vez: "...A cada uno de los géneros Alá ha concedido tareas distintas, la igualdad y la competición entre hombres y mujeres generan confusión; en el momento en que una mujer se meta en trabajos de pertenencia varonil, ella va a perder su naturaleza femenina. Acordes con su natura, las mujeres tienen que dedicarse al cuidado de los niños pequeños y mantener el hogar en orden y para evitar que la vivienda se convierta en un mercado, ellas deben refrenar su lengua y mortificar la curiosidad". Advocaban también que la prohibición para las mujeres de salir solas era una forma de protegerlas, para evitar que fueran víctimas de acoso, además de velar por su honor; las mujeres que se quedaban en casa sin trabajar recibían un sueldo por parte del gobierno. A parte de problemas de seguridad, Afganistán, debido a la destrucción de edificios escolares y a la falta de profesores y en condiciones de grave penuria de recursos, no disponía de una oferta educativa ajustada a la población femenina, pero serán puestos en marcha colegios femeninos cuando el país estará en condición de permitírselo; de sus palabras, quedaba claro que en aquel entonces la educación femenina no era considerada una prioridad. En cuanto a la conducta que debían seguir las mujeres un decreto proclamaba: "....Las mujeres no pueden permitirse atraer la atención de hombres inicuos que les dirijan miradas depravadas. Las mujeres son las responsables de educar y unir a su familia y son también responsables de las comidas y de cuidar del hogar... ". Esta aptitud de las esposas en la casa, que debe ser también un lugar de oración, es una manifestación de devoción hacia Alá.

Puesto que una de las consignas principales de los Talibanes, que habían desarrollado una mentalidad de plaza asediada, era preservar Afganistán de toda ideología extraña al Islam, además de protegerlo de la degeneración moral, el país tenía una estricta normativa de admisión en sus fronteras y la importación de muchos artículos fue prohibida. Los extranjeros, en particular los Occidentales, eran mirados con sospecha, considerando que podrían difundir modelos de vida contrarios al Islam. Que Occidente fuese lleno de corrupción era una convicción arraigada en la sociedad afgana de aquel tiempo y las personas desconfiaban de los Occidentales en general. Las ONGs que trabajaban allí y desempeñaban un papel importante, garantizando suministro de alimentos y asistencia humanitaria, sufrían muchas limitaciones que obstaculizaban sus actividades, algunas de las cuales 
han sido fuente de malentendidos. Los cooperantes extranjeros y cualquier visitante tenían que mostrar mucha cautela en su vida diaria, evitando de decir a las claras su opinión sobre el gobierno talibán y tener cuidado en no ofender la sensibilidad de las autoridades. Los Talibanes se sentían molestos con sus iniciativas, cuyas motivaciones no eran juzgadas sinceras, y además podrían tener una influencia perniciosa sobre la gente. Los cooperantes extranjeros, sometidos a muchos controles, y a los cuales se pedía tajantemente que se portasen siempre de acuerdo con las costumbres islámicas de allí, renunciando a lo que podría resultar contrario a estas, tuvieron que soportar numerosas muestras de hostilidad, si bien es verdad que muchos de ellos actuaban mostrando ignorancia y falta de respeto hacia las trádiciones del país. No se ha de extrañar, pues, que les fue ordenado que expulsaran al personal femenino afgano, y por fin los médicos occidentales y otros cooperantes, etiquetados, sin distinción, como idolatras y timadores, se marcharon del país, a pesar de que Afganistán se encontraba en situación de emergencia humanitaria y necesitaba expertos y mano de obra calificada. Frente a las protestas por parte de las ONGs occidentales, se les dijo: "Vosotros no sois musulmanes, por lo que no tenéis derecho a discutir sobre asuntos islámicos". ( Rashid, 209). Qari Dir Mohammed, el Ministro de Planificación afirmó: "Los Musulmanes creemos que Alá Todopoderoso va a alimentar todo el mundo de una manera $u$ otra. Si las Organizaciones No Gubernamentales extranjeras se van, entonces es su decisión. Nosotros no las hemos expulsadas".

En tanto que no musulmanes, los Occidentales que se encontraban en el país, eran vistos como posibles enemigos y a la población se recomendaba que evitara tener tratos con ellos. Un visitante extranjero, que tenía que estar siempre acompañado por un guía oficial y tampoco tenía la posibilidad de moverse libremente, no podía relacionarse de manera abierta con la gente y le estaba estrictamente prohibido hablar con las mujeres afganas. Además de las restricciones por parte de las autoridades, varias áreas estaban diseminadas de minas y explosivos, los transportes públicos apenas existían fuera de Kabul y las carreteras, en las cuales había muchos puestos de control, estaban en muy malas condiciones.

El gobierno de los Talibanes se caracterizaba también por el afán de transformar Afganistán en un foco de irradiación fundamentalista, de esta manera el país se convirtió en un centro de entrenamiento para muchos grupos radicales, a los cuales había proporcionado cobijo y ayuda. Habían llegado a ser muchos los jóvenes fundamentalistas, incluido algunos procedentes de países occidentales, vinculados por el objetivo común de la Yihad, que acudían en territorio afgano, adonde se encontraban también muchos refugiados de naciones islámicas que sufrían opresión. Los musulmanes extranjeros cobijados por el gobierno talibán, se les distinguía, a parte de su aspecto, por su actitud muy 
reservada y generalmente evitaban relacionarse con personas fuera de su grupo. Entre éstos, destacaban los militantes Árabes, cuya presencia iba aumentando de continuo, los cuales mantenían una actitud arrogante con los Afganos, considerándose superiores a ellos; a los ojos afganos, los Árabes y otros militantes extranjeros eran elementos extraños, tolerados, pero no amados, con los cuales la relación no resultaba fácil.

El gobierno talibán, al cual se le había multiplicado las acusaciones de fomentar el terrorismo y de distorsionar los principios del Islam, inquietaba tanto a Occidente como a los demás países islámicos, que criticaban su extremismo, señalando el peligro que esto suponía para todos, se encontraba aislado internacionalmente, aunque los Talibanes buscaran el reconocimiento de la legitimidad de su gobierno y desearan incrementar las relaciones con los otros países; a parte de Pakistán, Arabia Saudí y los Emiratos Árabes fueron los únicos en entretener relaciones diplomáticas con el gobierno talibán, pero incluido con aquellos Estados las relaciones no fueron fáciles y predominaba la mutua desconfianza. El apoyo talibán a Bin Laden amenazaba a la monarquía Saudí, ya acusada de custodiar indebidamente las dos mezquitas más sagradas del Islam y fuertemente criticada por la presencia en su territorio de tropas estadounidenses. Se vino a crear también un motivo de discordia entre Pakistán, considerado aliado de los Talibanes, e Irán, cuyo gobierno apoyaba a la Alianza del Norte, además de haber estrechado numerosos vínculos con Rusia, lo que alimentaba las sospechas en el bando talibán; después que en Agosto de 1998, 10 diplomáticos y oficiales iraníes fueron matados en el consulado iraní de Mazar- i Sharif, Irán había movilizado a miles de soldados en la frontera con Afganistán.

Bajo la alegación que Afganistán era un Estado que amparaba el terrorismo, el Consejo de Seguridad de la Naciones Unidas aprobó una resolución que imponía al gobierno afgano el embargo de armas, además de la incautación de sus cuentas al extranjero. Afganistán, que ya sufría sanciones por parte de la ONU, que acusó a los Talibanes de ser responsables de la matanza de unas miles de personas en Mazar - i Sharif, había sido objeto de recelo por casi todas las naciones, que tachaban a los Talibanes de proveer apoyo a varias organizaciones fundamentalistas, las cuales habían establecido allí campos de entrenamiento. Frente a la hostilidad de los otros países, que acusaban a Afganistán de representar una amenaza para la estabilidad de la región, los Talibanes, indiferentes a críticas y amenazas, se replegaron en su posición, negándose a extraditar a Bin Laden, que se había revelado un huésped incómodo y difícil de controlar, la alianza con el cual les había acarreado muchas complicaciones internacionales. La responsabilidad de los atentados atribuidos a Osama Bin Laden, entregar el cual violaría el código de hospitalidad pastún, recayó también sobre los Talibanes, responsables de darle refugio, los cuales 
afirmaban de no tener prueba de la culpabilidad de él. Ya en 1998 los EEUU, que exigían la extradición de Bin Laden, el cual había difundido una declaración de Yihad contra los EEUU (Elorza, 380-383), y veía en los Talibanes un apoyo importante a su lucha, habían lanzado unos mísiles contra las bases de Al Qaeda en Afganistán (Brieger, 54).

Bin Laden había afirmado:" El deber de todo musulmán es abatir donde quiere que pueda a los americanos y a sus aliados, civiles o militares (Rashid, 134). Merece la pena recordar que anteriormente, el gobierno de EEUU simpatizaba con los Talibanes, por la razón de que éstos se alineaban con la política antiiraní de Washington, y en aquel entonces Bin Laden, que había participado en la lucha contra el ejército soviético, estaba estrechamente vinculado con el gobierno estadounidense (Segura, 191-192). Unas compañías de petróleo, entre las cuales la estadounidense UNOCAL, esperaban que el proyecto, apoyado por el gobierno de Washington, de un gasoducto a través de Afganistán hubiera podido realizarse bajo el régimen talibán, al cual había hecho varias promesas, en el intento de asegurarse su colaboración a este proyecto, que nunca se concretizó (Requena, 117).

Al final se llegó a un profundo desentendimiento entre Occidente y el gobierno talibán, que poseído por un sentimiento de gran rabia frente a la postura hostil de la comunidad internacional, reacia a aportar ayuda humanitaria, decidió en Marzo de 2011 la destrucción de las famosas estatuas gigantes de Buda en el valle de Bamiyan, consideradas por la UNESCO patrimonio de la humanidad, acto que encabezó los primeros titulares de la prensa, provocando una explosión internacional de protestas. Por su parte los Talibanes hicieron oídos sordos al resto del mundo, acusado de mostrar más preocupación por unas estatuas que por la población afgana que pasaba hambre.

\section{Escuchando la opinión de los funcionarios Talibanes}

Intransigentes en materia de religión, los Talibanes, de acuerdo con la tradición afgana, tenían un fuerte sentido de la hospitalidad, y creían que quien, aunque no sea musulmán, visite Afganistán con actitud sincera y respetuosa, merezca ser acogido bien. Durante mi estancia, aunque limitada a no muchos días, he podido comprobar eso, y entre yo y algunos funcionarios gubernamentales vino a crearse una forma de mutuo respeto, por encima de las diferencias religiosas.

Entablando varias conversaciones con unos funcionarios, éstos, en diferentes momentos, se ofrecieron a explicarme, de manera informal, varios aspectos de su política, invitándome a no dejarme guiar por prejuicios o de afirmaciones por oídas. Si bien se decía que los Talibanes no fuesen muy dados al estudio, aquellos con los cuales hablé, aparte de su buen nivel de inglés, resultaron dueños de conocimientos 
bastante extensos y estaban al corriente de los asuntos que ocurrían fuera de Afganistán. En el curso de nuestras conversaciones, pese a las divergencias de opinión, se mostraban cordiales, pero, fieles a sus principios, eran resueltos en defender con firmeza la validez de su política y parecían tener respuesta para todo.

Mis preguntas, acompañadas de observaciones, y finalizadas a conocer de primera mano sus opiniones, ofrecieron a estos hombres, que parecían totalmente convencidos de estar siempre en lo cierto, una oportunidad para demostrar que sus decisiones estaban correctas.

En sus discursos, que naturalmente hacían especial hincapié en la religión, en primer lugar afirmaban de ser una guía para la población al fin de enseñarle a distinguir lo malo de lo bueno. Según su opinión, los seres humanos son incapaces de escoger voluntariamente lo correcto, y por eso es necesaria una continua orientación que les indique claramente lo que hay que hacer, al fin de que puedan dirigir todas sus actividades de manera conforme a la voluntad de Alá. En las condiciones de Afganistán, un país que por causa de la invasión soviética y de la guerra civil, se había hundido en una profunda oscuridad espiritual, era necesaria una autoridad fuerte e integra, dado que debido a los acontecimientos pasados muchos habían quedado presa de ideas contrarias al Islam... Alardeaban que por su mérito Afganistán estaba libre de toda ocupación extranjera y la vida había recobrado la normalidad, y los índices de violencia habían caído en picado, y que por primera vez Afganistán podría protagonizar su propia historia, de acuerdo con la voluntad de Alá, sin dejarse subyugar por nada. Dedicaron buena parte de su discurso a argumentar que ahora, gracias a su acción, los afganos habían vuelto a la práctica auténtica del Islam, acabando con las viejas costumbres y las supersticiones.

Según ellos, en Afganistán se estaba gestando una nueva civilización espiritual, la que muchos creyentes y pensadores islámicos anhelaban desde tiempo. A juzgar por sus palabras, que tal vez podían presentar unos aspectos convincentes, Afganistán era un lugar en el cual no había más corrupción, pero allá de las afirmaciones propagandísticas, la realidad era diferente.

¿Frente a la perspectiva de la vida eterna que valor podrían tener los asuntos temporales? Esta es la interrogación que hicieron en contestación a unas mías preguntas sobre eventuales proyectos de desarrollo económico. Considerando que la vida terrenal es breve y no sabemos cuándo nos tocará morir, cada uno debe hallarse preparado para el día de la muerte a fin de evitar el infierno, y por eso, conforme a su opinión, el verdadero progreso consiste en el crecimiento espiritual, para alcanzar el cual es precisa una ética de sacrificio y de continuo compromiso. La vida, que pertenece a Alá y debe dejarse guiar por Él, está concebida por fines nobles y no se puede someterla al azar. Por 
agradable que pueda ser nuestra existencia terrenal, no debemos olvidar nuestra condición de transeúntes; las comodidades materiales no pueden disminuir la ignorancia, y toda dicha terrena es fugaz y puede convertirse en lo contrario. Tomando el camino fácil, a un placer pasajero seguirá un largo sufrimiento, mientras que seguir la vía correcta puede resultar laborioso, pero al final llevará a la felicidad eterna. Contestando a una observación mía, basada en el hecho de que ya habían pasado casi cuatro años desde su toma del poder y el país se encontraba todavía en ruinas, afirmaron, con un cierto orgullo, que su primera preocupación ha sido la de proporcionar un ambiente apto para llevar una vida conforme a las prescripciones islámicas y no lo que concierne la vida material, en la convicción que las personas pueden ser buenos creyentes si el Estado en que viven está organizado en acuerdo con la verdadera tradición islámica y que ninguna nación carente de fuerza espiritual puede desarrollarse plenamente; en este sentido, hay que examinar la cuestión del desarrollo económico a la luz de una visión que considere el destino eterno del ser humano, teniendo en cuenta que los logros alcanzados en el ámbito espiritual suponen también una mejora de las condiciones de vida. La tarea del gobierno no puede limitarse al aspecto exterior, sino tiene un sentido mucho más importante, que es aquél de mostrar el camino correcto para llevar todos a la salvación, dado que solo la práctica sincera y auténtica de la religión puede dar carácter de pervivencia a una nación islámica. Si bien se mostraran conscientes de la necesidad de introducir en el país unas mejoras materiales y llegar a cubrir las necesidades de los más desfavorecidos, insistían que antes de reconstruir los edificios, era mucho más importante ayudar la población en recobrar el sentido espiritual. El Islam non es un obstáculo en el camino del progreso material, pero éste tiene que ser guiado por las leyes de Alá y no hay que aceptar el desarrollo científico a la manera occidental, sino poner un freno a lás tecnologías que, aunque prometan enormes beneficios, pueden desencadenar catástrofes. Todos los acontecimientos científicos poseen un valor limitado con respecto a la revelación de Alá, dueño absoluto de todo, de cuya señoría nada queda exente. En una ocasión el mulá Omar afirmó: "...El acontecimiento más importante hoy en día no es la invención del ordenador y de otras máquinas igual de absurdas, sino la renovación del Islam y de su misión: salvar al mundo de la ignorancia y educar a una humanidad que ha vuelto a la condición bestial..." (Gilbert, 87-88). Al hablar del desarrollo científico, este funcionario decía: "Lamentablemente la ciencia se ha convertido en el dios de este tiempo y la explotación masiva de los recursos, acompañada por la contaminación ambiental, sigue provocando efectos amenazadores para la vida humana".

El Ministro de Minas e Industrias Ahmed Jan había dicho: "...Queremos desarollar Afganistán como un Estado moderno y tenemos enormes recursos en minerales, petróleo y gas que deberían interesar a los 
inversores extranjeros..." (Rashid, 243). Acerca de este punto, especificaron que el gobierno no ha podido emprender todas las iniciativas que había planeado, debido a que tenía que concentrarse en la defensa contra las amenazas procedentes por varias partes, las cuales están intentando destruir el gobierno talibán.

Por lo que concierne la aplicación de normas estrictas y de castigos, explicaron que éstas, basados en los principios inmutables que Alá Todopoderoso ha revelado en el Corán, son necesarias debido a que el Estado debe velar por garantizar la seguridad tanto a nivel público como individual, y no puede permitir que cada uno actúe a su antojo; así que es necesario usar la fuerza para disuadir las personas de cometer delitos, puesto que los seres humanos, en la gran mayoría sumidos en la ignorancia, tienden a abusar de la libertad, la cual puede desembocar en la confusión y en el vicio, además de intensificar los problemas sociales. Sus alegaciones iban a parar en que la libertad no consiste en hacer lo que a uno le dé la gana, sino tiene que estar regida por la ley de Alá, en torno a la cual la sociedad debe organizarse, y por eso es necesario estar siempre alerta de lo que sea contrario a la voluntad divina. Como ya me habían explicado anteriormente, la sumisión a Alá, bajo cuyo control permanecen tanto el mundo como la historia, representa la mejor salvaguardia de la paz y permite asegurar el bienestar de todos; la pretensión de crear un mundo pacífico y justo, sin referirse a Alá, se ha revelado falsa; por mucho que lo intenten, quienes viven ignorando las leyes divinas no pueden lograr la verdadera felicidad. A su juicio, lo importante es la prevención de los actos delictivos, convencidos de que no se puede ser indulgentes con los culpables de crímenes, dado que la conducta errónea de uno pone en peligro la seguridad y el bienestar de todos; al demandar una mayor tolerancia se amenaza con conducir al país nuevamente al caos. Por consiguiente, caen en el pecado los que creen que la aplicación de las penalidades no sea apropiada y también los que consideren como permitido algo que está vetado. En las penalidades establecidas no hay que ver una voluntad de venganza, sino una medida disuasiva finalizada a intimidar las personas y quitarles cualquier deseo de cometer delitos. Es pertinente recordar que, de acuerdo con las normas coránicas, el castigo de un delito contra personas puede ser condonado si la víctima está dispuesta a perdonar el autor del crimen y aceptar una compensación. En su opinión, eso demuestra la superioridad del sistema jurídico islámico, el cual se remite a Alá como legislador supremo y no puede medirse con los parámetros de la justicia humana, viciada por muchas imperfecciones.

A continuación, llegando a hablar sobre el drama de los pueblos islámicos que se encontraban en situaciones de opresión y de conflicto, fue significativo escuchar su punto de vista sobre un asunto tan relevante, aunque yo fuera consciente que íbamos a adentrarnos en un tema delicado. Las naciones musulmanas como Palestina, 
Cachemira, Chechenia, Turkestán Oriental y otras, que sufren una larga y dura represión, en las cuales un sinfín de personas inocentes habían sido matadas y expulsadas de sus hogares, representan la evidencia de una conspiración mundial en contra del Islam, encabezada por EEUU, que, con la complicidad de varios países, quieren ejercer su hegemonía sobre todo el planeta. Por desgracia, sobre estas tragedias la comunidad internacional, hace la vista gorda, y una propaganda bien orquestada ha llegado a inculcar en la opinión pública la asociación de estos pueblos, que se han visto forzados a recurrir a la lucha armada para tograr la liberación, con el fundamentalismo islámico, y sus legítimas demandas son presentadas a través de una interpretación tendenciosa, inspirada en el desprecio hacia el Islam.

Otro argumento que esgrimían, con afirmaciones que no dejaban espacio para el debate, era que el Islam exige rebelarse contra las injusticias y las opresiones, así que ellos no pueden permanecer indiferentes frente al sufrimiento de estos hermanos suyos, víctimas de un terrorismo de Estado por parte de gobiernos inicuos, que han hecho derramar mucha sangre inocente. Sin embargo, no admitieron la implicación directa de Afganistán en apoyo a los grupos involucrados en la lucha armada, pero dejaron bien clara su posición de total solidaridad con aquellos, los cuales tienen el derecho de combatir contra toda dominación extranjera y resistirse ante las imposiciones de gobiernos impíos. En apoyo a sus alegaciones, citaban varias palabras del Corán, expresando la profunda confianza que los creyentes que ahora sufren opresión serán vencedores con la verdad, así como con las armas, y los que han muerto en la Yihad se han asegurado el paraíso. A su juicio para construir la paz es necesario ante todo, destruir el mal y no se puede confundir la lucha armada para la libertad con el terrorismo, del cual proclamaban de estar en contra; un claro ejemplo es el hecho que durante la ocupación soviética los Muyahidines eran calificados por el gobierno de la URSS como bandidos y terroristas, mientras que, en aquella época, los países occidentales los consideraban luchadores por la libertad. La definición "Fundamentalista islámico" ha llegado a ser una etiqueta que viene bien a EEUU y sus aliados, dados a la mentira con engañosas palabras de paz, para llevar adelante su política de opresión de las naciones islámicas.

La conclusión de su explicación, en la cual las palabras Alá e Yihad eran recurrentes y utilizadas como argumentos incontestables, era que muchas situaciones evidencian claramente la falta de justicia en el mundo. En las relaciones internacionales, priman los intereses económicos, en detrimento de los derechos humanos, por el hecho de que élites y potentados utilizan su poder para dominar la vida de todos. Con palabras contundentes, denunciaban que la hegemonía cultural de Occidente se ha vuelto en un sistema inhumano, en el cual muchas veces los animales disfrutan de más derechos que los seres humanos, y muchos niños se mueren de hambre y de enfermedades 
ante la indiferencia general, pero no hay que resignar a que la situación siga así.

Totalmente convencidos de que Alá estaba de su parte, echaban la culpa a las naciones occidentales que, inmersas en el materialismo y en la depravación, se ponen siempre en contra de los creyentes musulmanes. Acusaban a EEUU, percibidos como una encarnación del mal, cuyas impiedades se han difundido por el mundo entero, por su política, la cual respalda a los Estados que oprimen duramente los musulmanes, pero cualquier cosa que hagan, no podrán conseguir su intento, puesto que quien se ponga contra Alá, cuya justicia es infalible, pronto o tarde acabará derrocado, dado que no existe ninguna fuerza, por poderosa que sea, capaz de contrarrestar la voluntad de Alá, que todo lo vence y decide. Afirmando con énfasis que los hechos actuales no hacen otra cosa que confirmar el fracaso de las ideologías corrientes y la necesidad del Islam, calificaban el sistema democrático, en el cual los derechos humanos son más formales que reales, una chapuza para favorecer los intereses de los corruptos, mientras que amplias capas de la población se encuentran marginadas y pueblos enteros son víctimas de poderes políticos prepotentes y de fraudulentas tramas financieras. Con el paso del tiempo esta situación se ha ido a peor y el distanciamiento entre las naciones ricas y las pobres ha alcanzado dimensiones atroces.

Además de la sociedad occidental, tachada de vacío moral y adicta a muchos vicios, se proclamaban enemigos del marxismo ateo, así como de las monarquías del Golfo, consideradas corruptas y vendidas a los intereses extranjeros, y cuyas fastuosidad y lujo desenfrenado son una engañosa decoración para ocultar la traición del Islam. A los otros países musulmanes, acusados de haber caído en el adormecimiento de la fe y capitulado ante el laicismo, y cuyos gobernantes se han dejado llevar por el afán de riqueza y poder, contraponían sus esfuerzos para encarnar el verdadero espíritu islámico, ajeno a la frivolidad y al lujo. Sin embargo, a pesar de mi deseo de profundizar este tema, se mostraron remisos a discutir más detalladamente el asunto.

Considerando mi especial interés en la historia reciente de Afganistán, quisieron presentarme unos colegas suyos que habían participado en la lucha contra las tropas soviéticas; éstos, que habían visto la muerte cara a cara, hacían grande aprecio de la memoria de haber sido aquellos que contribuyeron a la liberación de Afganistán, negándose a aceptar el dominio de un país extranjero y ateo y se daban también los méritos por el derrumbe de la URSS, calificada como opresora de pueblos islámicos. Con sus palabras, querían darme a entender que ha sido Alá que les ha dado la capacidad para hacer cosas que, sin su amparo, hubieran sido imposibles. Lo que había garantizado la victoria no habían sido las ayudas materiales suministradas por EEUU, contrariamente a lo que generalmente se cree distorsionando la historia, sino la gran fe y el heroísmo de los Muyahidines que, a pesar de su inferioridad en cuanto a 
armamento y recursos, eran dispuestos a sacrificar su vida para la liberación de la patria. Los Muyahidines, que consideraban un privilegio morir luchando por el Islam, lograron trasformar lo imposible en posible en una condición de constante lucha sufrieron las inclemencias del tiempo, soportando las crudezas de las batallas, muchas veces durmiendo a la intemperie y padeciendo hambre y sed. Dos de ellos, que afirmaban de haber experimentado una especie de protección espiritual que les permitió derrotar los militares soviéticos, quisieron enseñarme, casi como si fueran una muestra de gloria, las heridas sufridas durante los combates, uno en la espalda y el otro en una pierna, presumiendo que su acción había contribuido a la victoria contra los ocupantes soviéticos. Los que encontraron la muerte en los combates ya eran parte de la leyenda y se les rememoraba con veneración y profunda gratitud, como los que habían abierto un nuevo camino de libertad y escrito páginas de heroísmo sin par, que quedan grabadas en la memoria de todos los afganos. Para ellos la lucha victoriosa contra los invasores soviéticos, que arrasaron muchas aldeas y mataron a miles de personas inocentes, ha sido un gran triunfo espiritual, que ha representado un punto de inflexión en la historia y ha beneficiado a las demás naciones islámicas, a las cuales ha mostrado claramente la posibilidad de derrotar a un poder inicuo, a pesar de la superioridad militar de éste. Ex combatientes mutilados, que llevaban en sus cuerpos las heridas y las amputaciones sufridas durante los combates, actuaban en puestos de gran responsabilidad en el gobierno talibán. En este sentido, la historia pasada resultaba útil para legitimar el presente, enseñando que el Islam podrá triunfar siguiendo el mismo camino que aquellos; es preciso recordar que los Talibanes interpretaban los hechos históricos a la luz de una concepción basada en la creencia de la inevitable victoria final del Islam en el mundo, convencidos que entregar la propia vida a la Yihad incumbe a todos los musulmanes. Con frecuencia recordaban que la empresa de los Talibanes, de muy difícil realización debido a las enormes dificultades y la limitación de sus fuerzas, ya desde su comienzo estuvo informada por un ideal sustentado por Alá y siempre gozaba de Su ayuda, en aquellas circunstancias de confusión y conflicto podrían haberse enriquecido fácilmente, pero decidieron vivir honestamente y dedicarse al servicio del Islam. Según ellos la historia de Afganistán quedaba dividida entre el periodo antes de ellos, que había sido todo un desastre, y la época después de su victoria y cuando hablaban de eso no podían ocultar su satisfacción. En sus declaraciones se manifestaba la convicción que Afganistán era predestinado por la realización de una sociedad islámica perfecta.

Sobre el mulá Omar, considerado por ellos un hombre de gran fe y extremada valentía, ajeno a todo tipo de corrupción y con un fuerte sentido de la justicia, cuya figura suscitaba profundo respeto, comentaban, sin entrar en detalles, que su actividad era incesante y 
seguía sacrificándose por el bienestar de su pueblo. Él no se ganó la buena reputación por casualidad, sino por dedicarse desde muy joven a servir Alá fielmente, luchando en primera línea y en los lugares más peligrosos, frente a enemigos aparentemente insuperables. Aunque su vida pasase por momentos muy duros de peligro y de extrema necesidad, nunca le faltó el valor para seguir adelante y su ejemplo contagiaba a todos los que entraban en contacto con él, cuyas palabras indicaban el camino a seguir; de no haber cumplido su misión, habría implicado la permanencia de Afganistán bajo la ocupación soviética. En el curso de esta conversación, que, en general, resultó interesante, se habían abstenido de mencionar la delicada cuestión de sus implicaciones con Al Qaeda, replegándose hacia unas afirmaciones genéricas y esquivando hábilmente mis preguntas acerca de este tema. En lo tocante a Bin Laden se limitaron a decir que él había ofrecido el sacrificio de su opulencia, renunciando a una vida acomodada, sólo movido por la fe, participando en los combates contra el ejército soviético y compartiendo con los Muyahidines todo tipo de peligros y necesidades.

Si bien tenían un ritmo repetitivo, sus discursos no carecían de argumentos interesantes, revelando sus aspiraciones y miedos a la vez, que ahora, a la luz de lo que pasó después, pueden entenderse mejor. Estos funcionarios se parecían a predicadores que no veían más que dos opciones: Islam fundamentalista o materialismo, y evitaban adentrarse en el análisis de los problemas reales, sin imaginar el desastre al que el país se encaminaba. En su exposición, en la cual la referencia a Alá y a Su voluntad era constante, varias cuestiones fueron pasadas por alto y cuando se presentaban preguntas incómodas, enarbolaban la retórica sobre la afirmación de estar construyendo una nación verdaderamente islámica y que a mí, debido a mi formación cultural occidental, resultaría difícil entender varios aspectos de su misión.

En recordar las conversaciones mantenidas con ellos, durante las cuales abordé una amplia gama de temas, que me habían dado mucho para pensar, según se desprendía de sus palabras, parecía que les impresionaba más las falsedades de los otros países islámicos, hacia los cuales sentían un profundo desprecio, que los pecados de Occidente. Si bien como funcionarios gubernamentales no podían salirse del guión, tras sus palabras, a las cuales, varias veces, no resultaba fácil dar sentido claro, podía percibir el deseo de enterarse un poco más sobre el mundo exterior, además de confrontarse con las opiniones ajenas. En un momento en el que su país tenía que hacer frente a muchas amenazas, en sus palabras se manifestaba la pretensión de justificar sus decisiones, que les había llevado a un dilema del cual no sabían como salir.

No hay duda que la postura de los países occidentales contribuyó a acentuar la orientación radical de los Talibanes, los cuales estaban muy preocupados, aunque no lo manifestaran abiertamente, de las 
consecuencias que acarreaba su decisión de apoyar a Al Qaeda. Quizás si Occidente se hubiera esforzado de tomar en consideración la grave emergencia humanitaria de Afganistán, no se hubiera llegado a la fuerte contraposición que llevó a los Talibanes a vincularse estrechamente con Bin Laden y a destruir las estatuas de Buda en Bamyan, decisión muy probablemente impulsada por él.

Hay que recordar que dentro del directivo talibán había profundas discrepancias entre una facción intransigente y otra partidaria de una política más abierta y pragmáfica, la cual, sin cuestionar abiertamente el liderazgo de Omar, era favorable a aligerar las rígidas normas impuestas y adoptar una actitud más flexible. Con mucha probabilidad con el paso del tiempo el régimen talibán se habría ido suavizando. Existía la posibilidad de que el mulá Omar se decidiera por fin a romper la alianza con Bin Laden, cuyas injerencias en los asuntos afganos se habían intensificado más y más, creándoles graves problemas, además de representar el mayor obstáculo para normalizar las relaciones con el resto del mundo. Nunca sabremos si realmente los Talibanes confiaban en Bin Laden o sí su amistad con él era sólo una maniobra política. Más allá de todas las coyunturas, parece claro que Omar quedó subyugado por la picaresca habilidad y el carisma de Bin Laden, acompañados de un enorme poder económico.

\section{Hacia un final trágico}

Lamentablemente los Talibanes acabaron por ser dominados por Osama Bin Laden, el cual les proporcionó una conspicua ayuda económica, en cambio haciendo de Afganistán, cuyo territorio fue utilizado como base para las actividades de su organización, el centro de una red fundamentalista; eso terminó por llevar al desastre todo el país. Los lazos que los unían a Al Qaeda estaban también basados en las relaciones personales y familiares entre Omar y Bin Laden, cuya hija mayor se habia convertido en la cuarta esposa del líder talibán.

$\mathrm{Si}$ bien los Talibanes, cuyo núcleo dirigente mostraba una homogeneidad étnica y cultural, pretendieran representar a todos los grupos étnicos, los Pastunes ostentaban la hegemonía, llevando a cabo una política de exclusión y hasta de persecución de las otras etnias, entre las cuales ya reinaba una profunda desconfianza hacia los Talibanes, cuyo gobierno había puesto en marcha un sistema coercitivo desligado de la realidad.

Muchos afganos pertenecientes a otros grupos étnicos creían que detrás del movimiento talibán, se escondía una nueva versión del nacionalismo pastún (Rashid, 139), cuyo liderazgo no querían aceptar Preocupados únicamente en que todos cumplieran con las normas de la Sharia, Ios Talibanes tropezaron con fuertes resistencias y protestas, 
frente a las cuales respondieron con la represión; además, sus austeros principios sufrieron deterioro, al descubrir que incluido muchos de ellos no los respetaban. La situación real era enmascarada por los discursos oficiales y dentro de una atmósfera de Islam radical, Afganistán escondía otras realidades. Bastaba con pasar un cierto tiempo allí para darse cuenta de que, varias veces, las consignas de los Talibanes tendían a caer en saco roto.

El gobierno talibán para el cual había sido fácil crear ilusiones, sin resolver los problemas de la gente, y cuyas medidas habían agravado la situación humanitaria de la población, se había revelado incompetente, acusado de someter la religión a sus intereses. La administración talibana no contaba con ningún experto calificado, de hecho casí todos los profesionales cultos se habían marchado y los ministros y sus ayudantes también eran mulás, la mayoría de los cuales poco instruidos, que no sabían mover la maquinaria estatal; las cuestiones económicas y sociales se interpretaban sólo en clave religiosa y casi nada se hizo en provecho del desarrollo del país, y muchas zonas se encontraban en estado de abandono total. El mulá Omar se había hecho más con la preocupación de complacer a Bin Laden que para solucionar los muchos problemas, agravados también por unos desastres naturales y por una serie de factores adversos que se habían acumulado, y con el paso del tiempo la situación había ido a peor. A un periodista pakistaní que en 1999 preguntó al mulá Omar acerca de la grave sequía que había golpeado Afganistán él afirmó: "Cuando el Profeta fue expulsado de La Meca, sobrevivió alimentándose de malas hierbas. Y además - añadió -, si pasamos hambre es un castigo de Dios por no ser musulmanes suficientemente piadosos". (Etienne, 87)

Sin embargo, sería muy fácil ahora echar a los Talibanes toda la culpa de las dramáticas condiciones en las cuales se encontraba Afganistán, pero no puede negarse que ellos encontraron un país totalmente arruinado, considerando además que la comunidad internacional no se preocupaba por la muy difícil situación del pueblo afgano el cual recibió una ayuda muy escasa, y cuyo sufrimiento importaba a pocos.

Lamentablemente después del 11 de Septiembre todo el pueblo afgano, erróneamente identificado con el radicalismo islámico, se convirtió en víctima de una criminalización, a pesar de que éste no tenía nada que ver con los terroristas que llevaron a cabo los ataques en Nueva York, y además estaba harto de la continuas interferencias de Al Qaeda en su país. En una reunión de clérigos en Kabul unos días después de los atentados del 11 de Septiembre el Mulá Omar dio un discurso en el cual dijo: "... Nuestro sistema es el verdadero ejemplo de un sistema islámico. Para los enemigos de la religión y de nuestro país, este sistema es como una espina en sus ojos, y están tratando de destruirlo con diversos pretextos. La afirmación de Osama Bin Laden como responsable de los ataques en Nueva York y Washington es una 
excusa. Afganistán no tiene recursos, ni Osama es tan poderoso, ni tiene contactos con el mundo exterior para llevar a cabo o planear este tipo de ataque. Tampoco no le damos permiso para utilizar el territorio afgano en contra de cualquier otro país...".

Hasta durante los ataques de la coalición internacional, los Talibanes mantenían la fe en poder lograr la victoria gracias a la ayuda divina y aseguraban que los bombardeos no afectarían a la resistencia. A pesar de que los Talibanes no tuvieran ninguna posibilidad de éxito frente a la enorme superioridad de sus enemigos, sus ilusiones se superponían a la realidad y nadie puede decir cuántos murieron apegados al sueño de una victoria imposible, persuadidos de que como ya habían vencido al ejército de la URSS, podían derrotar también a EEUU. El mismo mulá Omar había declarado en Noviembre de 2001 que la destrucción de EEUU se produciría dentro de un corto período de tiempo, si Alá lo quiere. En aquella ocasión afirmó: "Es una derrota que no puede ser evitada por el refuerzo de tropas ni por la formulación de estrategias consecutivas e irracionales. Es mejor que se elija la vía del razonamiento en vez del militarismo, además de poner un fin a la ocupación de Afganistán". De esta manera se encontraron sin otra posibilidad que la espera para una posible fuga o la muerte y fueron muchos los combatientes extranjeros que cayeron, dispuestos a morir más bien que rendirse, sobre la convicción de que había que defender Afganistán, como si fuera el último bastión del verdadero Islam. Unos portavoces de los Talibanes, cautivados con visiones de victoria que les impedían ver la realidad, hacían llamamientos a resistir hasta la muerte y seguían esperando un milagro que derrocaría a las fuerzas occidentales.

El mulá Omar terminó convirtiéndose en un fugitivo, cuyo destino se desconocía, y por la captura del cual el gobierno de Washington ofreció una recompensa muy elevada. En la imaginación de muchos musulmanes, convencidos que el movimiento talibán ha sucumbido militarmente, pero que su visión no ha sido derrotada, él está presente con el halo de un héroe, el cual ha dejado un ejemplo de entrega total a la causa del Islam, y su legado sigue inspirando a los grupos radicales, los cuales piensan que su misión dista mucho por haber concluido. Había rumores sobre su muerte ocurrida en Abril de 2013 en Pakistán, y más tarde la noticia fue confirmada.

A pesar de los graves errores cometidos por los Talibanes, no había una razón suficiente que pudiera justificar una operación bélica contra Afganistán. Si bien los medios de comunicación occidentales hayan intentado disimular los efectos del ataque, proyectando la imagen de una intervención militar actuada contra el terrorismo, aunque no se disponga de cifras fiables, los hechos hablaban de miles y miles de personas, incluido niños, mujeres y mayores, fallecidos y mutilados, a motivo de los bombardeos indiscriminados, además de muchos daños materiales, que aún resultan evidentes. A final del ataque, 
acompañado de venganzas y saqueos, quedaba un gran número de víctimas, muchas de las cuales hasta ahora sin amparo, reducidos a unas noticias de los informativos, que pronto han caído en el olvido. Centenares de Afganos, bajo sospecha de terrorismo, fueron detenidos sin ninguna garantía jurídica en la base estadounidense de Guantánamo, transportados allá, encapuchados y atados con cadenas, en aviones militares, y allá eran encerrados en pequeñas jaulas con los ojos y las orejas tapadas, sometidos a torturas y a interrogatorios extenuantes.

Han pasado ya varios años desde que el régimen talibán fue derribado, pero en la actualidad Afganistán, todavía uno de los países más pobres del mundo y cuyo futuro está expuesto a graves riesgos, está viviendo una convúlsa situación. No se puede negar que la caída de los Talibanes ha supuesto el fin de muchas restricciones, si bien numerosos problemas siguen iguales, todavía muchos afganos están en situación de inseguridad alimentaria y el tráfico de drogas y de armas está fuera de control; las mujeres, muchas de las cuales todavía visten el burka, siguen sufriendo varias discriminaciones, aunque logren ser representadas en el parlamento. No hay un dirigente para gobernar el país aceptado por todos los grupos étnicos y varios personajes con un pasado turbio ahora ocupan posiciones importantes y señores de la guerra y narcotraficantes controlan el parlamento (Bernabé, 126-127), con el apoyo implícito de la comunidad internacional. Todavía los grupos talibanes que luchan contra el actual gobierno y las tropas internacionales que lo sostienen, vistas por varios sectores de la población como una fuerza de ocupación, cuyas operaciones militares han provocado varias víctimas, mantienen control en varias zonas del país, y, de vez en cuando, organizan ofensivas. En estos últimos tiempos con la emergencia del ISIS, la situación se ha ulteriormente agravado, pero Afganistán es un país imprevisible y como afirmó al comienzo del siglo pasado Lord Curzon, virrey de las Indias: "Todos los que han hecho previsiones sobre Afganistán, se han equivocado". 


\section{Referencias bibliográficas:}

BALLESTEROS, A. (2011), Pakistán, Madrid: Editorial Síntesis

BATALLA, X. (2002) Afganistán. La guerra del siglo XXI, Barcelona: Plaza \& Janés Editores

BERNABÉ, M. (2012), Afganistán, Barcelona: Random House Mondadori

BLANCARTE, R. J. (2001), Afganista'n. La revolución islámica frente al mundo occidental: Ciudad del Me'xico: El colegio de Me'xico

BRIEGER, P. (2006) Que es AI Qaeda, Buenos Aires: Capital Intelectual

DE LA TORRE, I. (2005) El radicalismo desvelado, Madrid: Lid Editorial y Editorial Dilema

ELORZA, A. (2002) Umma: el integrismo en el Islam, Madrid: Alianza Editorial

GILBERT, E. (2002), Imprevisible Afganistán, Barcelona: Edicions Bellaterra

GOMÁ, D. (2011) Historia de Afganistán: de los orígenes del Estado afgano a la caída del régimen talibán, Barcelona: Editorial Universidad de Barcelona

GRIFFIN, M. (2001) El movimiento talibán en Afganistán: cosecha de tempestades, Madrid: Los libros de la Catarata

KEPEL, G. (2001) La yihad: expansión y declive del islamismo, Barcelona: Editorial Península

MARSDEN, P. (2002) Los talibanes, Barcelona: Editorial Grijalbo Mondadori

RASHID, A. (2002) Los talibán: el Islam, el petróleo y el nuevo "Gran Juego" en Asia Central, Barcelona: Editorial Península

REQUENA, P. (2011) Afganistán, Madrid: Editorial Síntesis

SEGURA, A. (2001) Más allá del Islam, Barcelona: Alianza Editorial

TONCHEV, P. (2006) Pakistán. El Corán y la espada, Madrid: Los libros de la Catarata

TORTAJADA, A. (2001) El grito silenciado. Diario de un viaje a Afganistán, Barcelona: Editorial Grijalbo Mondadori 